\title{
Government's Activities for Counterterrorism: Min-Max Differential Game Approac
}

\author{
Abdelmonem Megahed $^{1}$, E. Youness ${ }^{2}$, and H. K. Arafa ${ }^{1}$ \\ ${ }^{1}$ Suez Canal University \\ ${ }^{2}$ Tanta University Faculty of Science
}

May 5, 2020

\begin{abstract}
One of the main problems facing governments at present is terrorism. Most recent studies are striving to find an optimal solution to this problem that threatens the security and stability of peoples. To combat terrorism, government uses various means such as: education development, providing labor opportunities, seeking social justice, religious awareness, and security arrangements. The purpose of this research is to evaluate the optimum strategy for both government and terrorist organizations using Min-Max differential game approach. Also, a saddle point concept for this game was discussed
\end{abstract}

\section{Hosted file}

terrorELRJS_corresponding_author (1).pdf available at https://authorea.com/users/300172/ articles/429859-government-s-activities-for-counterterrorism-min-max-differential-gameapproac 
figures/22/22-eps-converted-to.pdf 
figures/44/44-eps-converted-to.pdf 